\title{
RAS DAN HOMOSEKSUALITAS: GAGASAN JAMES BALDWIN DALAM ANOTHER COUNTRY
}

\author{
Tisna Prabasmoro ${ }^{1}$ \\ Rasus Budhyono ${ }^{2}$
}

Fakultas Ilmu Budaya Universitas Padjadjaran

\begin{abstract}
ABSTRAK
Penelitian ini mencoba untuk ikut menyumbangkan gagasan-gagasan pada diskusi tentang isu-isu ras dan homoseksualitas yang pelik di Amerika Serikat pada tahun 1960-an. Agar dapat mendekati permasalahan yang kompleks ini, penelitian membahas novel karangan James Baldwin berjudul Another Country, yang menantang supremasi kulit putih dengan pemikiran-pemikirannya perihal identitas pribadi dan sosial. Pada penelitian ini Another Country dimanfaatkan untuk menunjukkan pentingnya pemikiran-pemikiran Baldwin tentang identitas personal dan sosial, berkaitan dengan pengenalan dam pengakuan diri seseorang sebagai manusia, yang menjadi lokus pendukung perubahan sosial yang diperlukan untuk terciptanya keselarasan hubungan-hubungan di Amerika Serikat. Penelitian ini mencoba untuk menganalisis kehidupan dan karya Balwin terhadap perkembangan politik pada masanya, dan dengan meminjam konsep-konsep identitas, untuk menunjukkan bagaimana dikotomi warga berkulit putih dan hitam adalah pengalaman-pengalaman hidup Baldwin yang paling mengganggu, namun bermakna. Penelitian ini juga pada akhirnya menunjukkan bahwa dengan mempelajari Baldwin sebagai individu dan anggota masyarakat, kita dapat menafsirkan eksistensi dan ekstensi dikotomi yang tidak berterima tersebut: keunggulan warga berkulit putih disamakan dengan keumuman heteroseksualitas dan kemarjinalan warga berkulit hitam dengan keterasingan homoseksualitas.
\end{abstract}

Kata kunci: Baldwin, identitas, ras, homoseksualitas

\begin{abstract}
This paper seeks to contribute to discussions of the intricate issues of race and homosexuality in the United States in the 1960s. In order to elucidate one possibility of approaching this complex issue, the paper discusses James Baldwin's Another Country, which challenges the notion of white supremacy. Thus, it argues that Baldwin's novel can be used to show the significance of his ideas pertaining to his personal and social identity, the recognition and acknowledgment of oneself as a being, which is the locus for what promotes the social transformation necessary to create just and equal social relations in the United States. The paper attempts to analyze Baldwin's life and work against the development politics of his time, and, by borrowing from concepts of identity, to show how, for Baldwin, the white-versus-black dichotomy is his most disturbing, and yet meaningful, experience. The paper eventually argues that by studying Baldwin as an individual and a society member, one can construe the repulsive existence and extension of the dichotomy: that whiteness is equated with heterosexuality and blackness with homosexuality. Keywords: Baldwin, identity, race, homosexual
\end{abstract}

\footnotetext{
1 Program Studi Bahasa dan Sastra Inggris, Fakultas Ilmu Budaya, Universitas Padjadjaran
}

2 Program Studi Bahasa dan Sastra Inggris, Fakultas Ilmu Budaya, Universitas Padjadjaran 


\section{PENDAHULUAN}

Sebagai sebuah gagasan atau ide dan amanat utama, tema cerita adalah persoalan atau pokok pembicaraan yang mendasari cerita, dan kemudian yang disajikan dan diuraikan dalam berbagai bentuk tulisan oleh pengarang. Sebagai sebuah landasan yang menjadi bantalan gagasan sentral, yaitu sesuatu yang hendak diperjuangkan melalui suatu karya, tema memberikan rumusan dan rangka tujuan penulisan yang akan dicapai oleh pengarang (Wellek dan Warren, 1977 dan Keraf, 1993). Penjelasan tentang tema kemudian menjadi penting karena hal tersebut adalah dasar dari penelitian sosial dan humaniora dan bagi para peneliti lain dari bidang yang sama atau lintas bidang atau lintas posisi epistemologi agar mereka dapat menjelaskan dan meneruskannya lebih lanjut pada penelitian yang lain, atau membandingkannya dengan data/ penelitian sebelumnya (Ryan dan Bernard, 2003).

Dalam hubungan dengan proses kreatifnya, pengarang berkuasa penuh pada penentuan tujuan penulisan dan proses penciptaan - mereka cipta tokoh, memberi tempat bagi narator/ karakater untuk bersuara, menentukan latar, bereksperimen dengan gaya bahasa dan sudut pandang, hingga menetapkan ketegangan, konflik dan penyelesaian. Dengan perkataaan lain, pengarang memiliki hak istimewa dalam menentukan tema cerita yang dibebat dalam konteks-konteks atau aspekaspek identitasnya (etnisitas, psikologi, dan sejarah, misalnya) yang mendukung keberhasilan penceritaan tersebut. Namun demikian, dalam kaitannya dengan hubungan pembaca dan pengarang, suatu kajian memaparkan bahwa pengarang adalah bukan penafsir tunggal tulisan yang sudah berada di tangan pembacanya. Tafsiran-tafsiran pembaca akan menggantikan kuasa pengarang dan para pembaca dan kritikus menjadi pengarang-pengarang yang menentukan sendiri makna sebuah karya. Dari perspektif ini dapat disimpulkan bahwa kuasa pemaknaan bukan milik satu orang, pemaknaan tidak ada pada teks, tetapi ada pada diri masing-masing pembaca, dan bahwa ketika sebuah karya menemui pembacanya maka pengarang dapat dikatakan menjadi tidak penting dan bahkan 'mati' dalam proses penafsiran pembaca (Barthes, 1998). Hal ini menjadi menarik ketika kajian yang lain beranggapan bahwa suatu karya tidak terbentuk dengan tiba-tiba dan dapat dihubungkan dengan gagasan atau pemikiran penulisnya. Kajian ini menguraikan bahwa pluralitas signifikansi (makna) teks - atau karya, sebagai hasil akhir imajiner suatu teks, dapat direduksi dengan mengaitkan (latar belakang, identitas) pengarang yang hadir sebagai narator/ karakter pada sebuah karya dan memaparkan gagasannya. Dengan demikian, identitas, lingkungan atau keadaan (ekonomi atau sejarah, misalnya) di sekitar karangan tempat terjadinya proses penulisan dan tanggapan total pengarang terhadap pengalaman hidup dan hubungannya dengan dunia dapat mempersempit lingkup kemungkinan-kemungkinan makna suatu karya. Konteks tidak menentukan makna kata, tetapi menentukan rekaan penafsir, dan konsep wacana tetap melihat realitas sosial, atau kondisi-kondisi yang dapat dan tak dapat dikemukakan dalam karya, sebagai arena diskursif (Foucault, 1980 dan Heraty, 2000).

Sebagai seorang penulis Amerika berkulit hitam yang menjadi corong gerakan persamaan rasial khususnya selama gerakan hak sipil pada tahun 1960an, James Arthur Baldwin (1924-1987) banyak dikenal sebagai penulis novel semiotobiografis yang menyampaikan permasalahan rasial dalam novel, drama, koleksi esai dan kumpulan puisi: The Amen Corner (1950), Go Tell It on the Mountain (1953), Another Country (1962), The Fire Next Time (1963), Blues for Mister Charlie (1964), Going to Meet the Man (1965), Tell 
Me How Long the Train's Been Gone (1968), If Beale Street Could Talk (1974), Just Above My Head (1979), The Devil Finds Work (1976), The Price of the Ticket (1985) dan Jimmy's Blues (1985). Ketika Baldwin mulai menyadari ketertarikan seksualnya terhadap sesama jenis, Baldwin pergi ke Paris dan menulis Giovanni's Room (Campbell, 1991; Miller, 2000).

Penelitian ini berfokus pada penyampaian dan analisis gagasan James Baldwin pada Another Country yang dihubungkan dengan identitas personal dan sosialnya. Pada akhirnya, penelitian ini menunjukkan bahwa pemikiran James Baldwin pada karya tersebut tersebut tidak hanya mendokumentasikan tetapi juga merupakan respon dari kenyataan kehidupan masyarakat Afro-Amerika yang terpuruk, yang terdiskriminasi oleh kekuatan-kekuatan sosial dan hukum dalam supremasi kulit putih, salah satunya dikenal dengan kebudayaan WASP (White Anglo Saxon Protestant), yang anti integrasi dan, tentu saja, yang diciptakan oleh kelompok masyarakat kulit putih.

\section{METODE PENELITIAN}

Untuk sampai pada tujuan penulisan, penelitian ini menggunakan metode deskriptif analisis yang membahas konteks-konteks atau aspek-aspek identitas James Baldwin melalui perspektif Eckman (1966), Gutmann (1994), Woodward (1999), Hawthorne (2000), dan Nelson (1985). Implementasi metode ini didukung oleh studi pustaka, yang pada prakteknya adalah penelitian kepustakaan untuk menganalisis data yang terdapat pada Another Country dan menghubungkannya dengan konsep-konsep identitas untuk dapat memunculkan tafsiran tema dan mendedahkan gagasan-gagasan James Baldwin.

Latar belakang pemilihan dan pengaplikasian konsep-konsep identitas pada penelitian ini adalah karena konsep-konsep tersebut memungkinkan pembacaan yang lebih jelas dan memberikan sumbangan besar pada studi subkultur, suara-suara yang marjinal dari budaya dominan (Lazuardi, 1999). Konsep-konsep tersebut juga memungkinkan explorasi hasil-hasil kebudayaan dari anggota-anggota kelompok minoritas, seperti James Baldwin yang tidak hanya berkulit hitam tetapi juga seorang homoseksual, sekaligus mencoba menjawab pertanyaan Spivak: Can subaltern speak?, yang diajukannya pada tahun $1985^{3}$. Dapat dikatakan demikian karena melalui kajian ini kemudian dapat ditelusuri dan dipahami bersama bahwa suatu karya adalah suatu usaha untuk 'berbicara' atau 'membunyikan' suara-suara yang sebelumnya tidak diartikulasikan, atau telah diartikulasikan namun tidak tertangkap makna suara yang teropresi tersebut.

\section{PEMBAHASAN}

Sekilas Another Country adalah cerita cinta yang menyiksa antara laki-laki dan perempuan dan homoseks, yang berkulit hitam dan putih, dan ditunjukkan melalui hubungan-hubungan dinamis dalam sebuah lingkaran pertemanan. Rufus adalah seorang laki-laki berkulit hitam yang ditinggalkan kekasih berkulit putihnya, Leona, dan menjadi seorang homoseksual sebelum akhirnya bunuh diri. Vivaldo adalah seorang penulis tidak mapan berketurunan Irlandia-Italia yang menyayangi Rufus, dan juga adik perempuan Rufus, Ida. Cass dan Richard pada awalnya adalah sepasang kekasih berkulit putih hingga Richard menjadi seorang penulis terkenal dan Cass menjalin hubungan cinta dengan Eric, yang juga seorang homoseksual dan

3 Pertanyaan diajukan kembali oleh Gandhi (1998:1). Subaltern diartikan sebagai kelompok-kelompok inferior atau yang teropresi. 
menjalin hubungan dengan Rufus dan pemuda Perancis, Yves. Dalam perkembangan plot Another Country, orang yang berkulit putih berpasangan dengan yang berkulit hitam, heteroseksual berpasangan dengan yang homoseksual, homoseksual berpasangan dengan perempuan, dan semuanya tidak hanya terjadi berdasarkan pada nafsu atau hanya ingin menantang keadaan. Hubungan-hubungan tersebut juga diselimuti dan dikuasai oleh emosi dan perasaan para pelakunya. Dengan banal dan naif mereka terus berbicara tentang keinginan-keinginan dan penderitaan. Cerita diakhiri dengan kenyataan tragis bahwa kebenaran yang ditemui dan berlaku di sekitar mereka membawa keputusasaan yang mematikan cinta mereka.

Dalam salah satu deskripsinya tentang hubungan Rufus dan Vivaldo, Baldwin menulis,

[t]hey encountered the big world when they went out into the Sunday Streets. It stared unsympathecally out at them from the eyes of the passing people; Rufus realized that he had not thought at all about this world and its power to hate and destroy (Another Country, 1962:27).

Dunia Rufus dan Vivaldo adalah dunia kecil yang harus mereka ciptakan sendiri dan dunia kecil tersebut dipenuhi oleh pengaruh-pengaruh yang menolak dan membedakan. Atas dunianya ini Baldwin memerlukan suatu bentuk kejelasan untuk menemukan identitas dirinya. Kejelasan ini bergantung kepada transparansi dari pengungkapan teks yang diciptakannya dan pernyataan atas pembebasan dirinya, tanpa mempedulikan apakah suatu bentuk pernyataan pembebasan berhubungan erat dengan ijin yang diberikan orang lain kepadanya. Pembacaan teks Baldwin yang demikian kemudian memungkinkan wacana ras dan seksualitas untuk masuk dalam tinjauan kritis yang mengarahkan pembaca untuk melihat dan menganalisis penghalang atau rintangan yang dimaksudkan Baldwin sebagai pemisah dan bahkan pemecah belah suatu kelompok.

Membaca dunia Rufus yang kecil dan dikelilingi oleh penolakan dan pembedaan mengingatkan pembaca akan kehidupan Baldwin sendiri. Baldwin dilahirkan di kota Harlem ${ }^{4}$ dan tumbuh dalam keluarga yang miskin dan berkembang dalam pengawasan ayahnya yang disiplin dan agamis. Pengalaman sejak kecil Baldwin yang telah menjadi korban risak oleh para polisi New York dan warga berkulit putih di sekitar pemukiman kemudian membawa dirinya pada penulisanpenulisan tentang penolakan sosial, dan kesendirian (Baldwin and Standley, 1989). Dalam prosesi pemakaman Rufus, sang pendeta berkata, "don't none of us know what goes on in the heart of someone ... and so can't none of us say why he did what he did. Ain't none of us been there and so don't none of us know" (Baldwin, 1962:473). Bahwa untuk mengerti mengapa Rufus mengakhiri hidupnya, Baldwin beranggapan bahwa pembaca harus menginternalisasi dan meresapi penderitaan Baldwin dan Rufus.

Penderitaan yang dialami karakter-karakter di dalam novel memberikan dan menjadikan modal sekaligus kekuatan untuk berkaca perihal diri mereka, untuk bertanggung jawab atas segala perbuatan mereka. Another Country dalam cermatan kulit luar memang hanya menampilkan kehidupan homoseks, namun cermatan yang lebih memadai akan membawa pembaca kepada wacana kelompok minoritas yang

\footnotetext{
4 Kota Harlem adalah kota pemukiman warga Afrika-Amerika di New York. Selain dikenal sebagai kota dengan jumlah kemiskinan dan kejahatan meningkat tajam sejak Perang Dunia II, Harlem juga menjadi pusat gerakan pembebasan dan literasi yang dikenal dengan Harlem Renaisance (Gates, 1997)
} 
lain yang dapat dipadankan dengan wacana ras minoritas yang memang sudah ada sebelumnya. Ketika Vivaldo (yang berkulit putih) bertanya, "They're colored and I'm white but the same things have happened... and how can I make them know that?" (Baldwin, 1962:113), Vivaldo sedang memosisikan dirinya sebagai kelompok minoritas berkulit putih karena dirinya berbaur dengan kelompok yang tidak berkulit putih. Pada bagian ini Baldwin sedang menyampaikan bahwa sebenarnya orang kulit putih homoseksual di Amerika, berada pada nasib yang sama dengan orang hitam yang teropresi. Mereka senasib dalam hal orang lain - heteroseksual - melihat dan menghakimi pilihan seksual mereka. Hanya saja kenyataan lain, yaitu mereka berkulit putih, menjadi faktor penting yang menolong, yang tidak membuat nasib mereka lebih terpuruk seperti halnya yang dirasakan dan dialami oleh orang kulit hitam. Akan 'keberuntungan' homoseksual kulit putih ini Baldwin menyimpulkan bahwa apabila bentuk kehidupan kelompok homoseksual dapat diangankan orang kulit putih, maka kelompok orang hitam yang homoseksual pun boleh mengangankan, paling tidak, bentuk yang sama. Dalam artian lain, kengerian, kejijikan kaum heteroseksual kulit putih yang homofobia tidak hanya ditujukan kepada kelompok homoseksual yang berkulit berwarna saja. 'Keberuntungan' homoseksual kulit putih seharusnya tidak menolong mereka sama sekali, dan hal itulah yang menjadikan mereka berada dalam satu perahu dengan homoseksual kulit hitam: keduanya sama-sama dipinggirkan, tidak diuntungkan dan menjadi masyarakat yang minor. Jawaban yang negatif terhadap pertanyaan apakah hal yang tersirat ini merupakan kritik sosial Baldwin terhadap orang kulit putih Amerika, saya menganggap bahwa jawaban negatif yang muncul malah akan semakin menunjukkan ketidakadaan pengakuan orang kulit putih terhadap hubungan antara homofobia dan rasialisme, dan lebih jauh lagi, penolakan terhadap identitas. Meskipun pada Another Country Rufus 'dimatikan' oleh Baldwin, dan Ida 'dikonstruksikan' menikah dengan Vivaldo - yang berarti dapat dibaca sebagai simbol tunduknya kulit hitam kepada kulit putih - hal ini bukanlah penanda terlalu jauhnya tafsiran pembaca terhadap Another Country, namun justru menunjukkan besarnya, dan kompleksnya, hubungan antara homofobia, rasialisme dan identitas yang membutuhkan tawar menawar keuntungan dan kerugian yang harus dilakukan Baldwin sebagai penulis.

Berbicara mengenai penunjukkan identitas pribadi adalah juga berarti berbicara mengenai penyingkapan. Dalam perjalanan mencari dan menuju keaslian dan penerimaan diri, para karakter dalam novel ini tidak hanya bertolok ukur kepada pemahaman diri mereka terhadap diri mereka sendiri tetapi juga pada anggapan konvensional orangorang di sekeliling mereka terhadap diri mereka. Pemahaman diri mereka terhadap diri mereka sendiri terwujud dalam pengakuan sejujurnya akan kesalahan-kesalahan dan batasan-batasan yang mereka miliki, sementara usaha untuk diterima oleh kelompok lain ditempuh dengan berkompromi dengan anggapan-anggapan umum tanpa melepaskan identitas pribadi. Perjalanan tersebut kemudian menjadikan Another Country terus membicarakan pengamatan yang teliti dan kewaspadaan atas kemampuan diri sendiri yang bermuara pada bentuk penyingkapan-penyingkapan. Selain menjalin kelekatan diantara para tokohnya, penyingkapan 'rahasia diri' yang terus memenuhi isi novel ini juga menandai kesedihan mereka yang kadang sulit untuk diverbalkan.

Dalam artian lain, Baldwin mencoba menerima siapa dirinya sebelum mendapat atau meminta pengakuan (recognition) dari orang lain. Baldwin merasa harus berdamai dulu dengan dirinya yang homoseksual sebelum dunia disekitarnya harus mengakui kehomoseksualannya. Penyingkapan diri yang setengah-setengah 
atau malu-malu dalam pemikiran Baldwin tidak akan melahirkan pengakuan seperti yang diinginkan, dan apapun konsekuensi dari segala bentuk penyingkapan itu - baik berupa kesedihan, kemarahan ataupun hinaan dan pendiskriminasian - yang penting disadari adalah makna dari upaya menunjukkan jati diri tersebut bagi dirinya.

Dalam hubungannya dengan teks dan tafisiran pembacaan Another Country, pembaca dapat melihat bahwa Baldwin menerima kenyataan dirinya sebagai seorang homoseksual dan berharap penuh Amerika menerima akan melakukan hal yang sama. Oleh Baldwin, Amerika yang disebutkan sebagai the land of the free and the home of the brave (Eckman, 1966:15). Penyebutan ini sekaligus mempertajam ironi yang dimaksudkannya. Sebagai seorang yang hidup di Amerika, Baldwin malah justru tidak dapat mengungkapkan kebebasannya dengan menentukan sendiri pilihanpilihannya. Kehomoseksualan seseorang bisa jadi bukan merupakan suatu pilihan, namun merupakan suatu dampak dari situasi dan keadaan yang menyeretnya ke dalam kondisi ini. Namun ketika kehomoseksualan seseorang adalah suatu pilihan gaya hidup, maka apa yang dipilih Baldwin seharusnya dilindungi, karena hal tersebut adalah ekspresi kebebasannya. Negara yang juga dikatakan Baldwin sebagai the home of the brave ini ternyata tidak cukup berani untuk menerima kenyataan akan perbedaan seseorang. The brave dalam konteks ini hanya mengacu kepada orangorang yang telah memberikan hidupnya untuk negara. The brave hanya mengacu kepada jasad para pahlawan yang telah gugur dan dikuburkan di peristirahatan terakhirnya. Tanpa mengecilkan jasa para pahlawan tentu saja, saya menginterpretasi bahwa Baldwin ingin juga mengatakan bahwa the brave yang telah gugur pada hakikatnya juga menginginkan suatu kebebasan negaranya, yang berarti juga kebebasan para warga negaranya. Namun, dalam pemikiran Baldwin, Amerika telah gagal dalam menerjemahkan kebebasan warganya di negara yang bebas.

Perihal latar Another Country, Baldwin menginginkan pembacanya untuk melihat New York, dengan Harlem dan Greenwich Village, sebagai tempat yang peradabannya terdisintegrasi. Ketika Eric tiba di New Work meninggalkan pasangannya Yves di Paris, permasalahan kehomoseksualan dirinya menjadi kengerian bagi dirinya.

New York seemed very strange indeed. It might, almost, for the strange barbarity of manner and custom, for the sense of danger and horror barely sleeping beneath the rough, gregarious surface, have been some impenetrably exotic city of the East... It seemed to have no sense whatever of the exigencies of human life; it was so [familiar] and so [public] that it became, at last, the most despairingly private of cities. One was continually being jostled, yet longed, at the same time, for the sense of others, for a human touch; and if one was never - it was the general complaint - left alone in New York, one had, still, to fight very hard in order not to perish of loneliness. . This note of despair, of buried despair, was insistently, constantly struck (ditebalkan penulis, 230-31).

Kutipan ini memperlihatkan bagaimana kontradiksi memainkan peranan yang penting dalam menggambarkan kota New York. Kutipan ini dibangun disekitar dua rangkaian yang mulai memudar: familiar dan public. New York menjadi the most despairingly private of cities, tidak pernah left alone namun tetap membiarkan seseorang yang datang merasakan loneliness yang menyesakkan. Keruntuhan ini adalah juga melambangkan New York yang sulit untuk dipahami Eric dan karakter-karakter lainnya yang merasakan perbedaan harapan yang dijanjikan New York dan ketertutupan orangorangnya yang melahirkan kekecewaan yang mendalam. Meraga dalam Eric, Baldwin 
mengutarakan kengerian, kesendirian dan keputusasaannya berada di suatu tempat yang baru. Perasaan-perasaan tersebut bagi seorang homoseksual di tempat yang seperti ini adalah suatu kelaziman karena tempat baru adalah juga berarti kembali mengingatkan dirinya yang homoseksual yang tidak dapat meniadakan perasaan dan anggapan orang-orang di sekitarnya yang bertendensi negatif.

Dalam hubungan dengan konsep identitas dan recognition, Gutmann (1994:149-164) membagi identitas menjadi dua bagian besar; identitas kolektif sosial dan identitas pribadi. Identitas kolektif sosial mengacu pada agama, gender dan seks, etnis dan ras, yang masing-masing disikapi manusia secara berbeda-beda. Agama mewariskan kepercayaan-kepercayaan, dogma-dogma, dan ideologi yang dijadikan sandaran pemeluknya dalam berkomitmen terhadap agamanya. Seks dan gender tidak hanya berhubungan erat dengan tubuh, tetapi juga norma-norma perilaku, kebiasaan berpakaian dan karakter pribadi yang dipahami manusia secara tidak seragam berdasarkan pada tempat dan waktu manusia hidup. Pemahaman yang berbeda-beda inilah yang menurut Gutmann membutuhkan pengakuan atas identitas yang berbeda-beda tersebut. Pada kelompok homoseksual, misalnya, ketiadaan pengakuan terhadap diri mereka akan menjadikan mereka kelompok minoritas yang pada akhirnya bermuara pada tindakan-tindakan diskriminasi terhadap mereka. Hal yang sama bisa saja terjadi pada kelompok-kelompok etnis yang dalam kehidupan sosialnya menganut pembagian kasta, klan atau yang lainnya.

Setelah menghadiri pemakaman Rufus, Cass merenungi rahasia yang tidak diungkapkan Vivaldo:

Perhaps such secrets, the secrets of everyone, were only expressed when the person laboriously dragged them into the light of the world, imposed them on the world, and made them a part of the world's experience. Without this effort, the secret place was merely a dungeon in which the person perished; without this effort, indeed, the entire world would be an uninhabitable darkness; and she saw, with a dreadful reluctance, why this effort was so rare (ditebalkan penulis, 112).

Hal ini mengilustrasikan gagasan Baldwin bahwa dengan keberanian seseorang dapat menghadapi dan memikirkan dengan seksama rahasia-rahasia terpendamnya. Tidak cukup sampai disitu, dunia juga sebaiknya tahu akan rahasia-rahasia tersebut sehingga dunia dapat menjadikannya bagian dari dirinya. Meskipun demikian, rahasia akan juga samar bahkan bagi orang yang menyimpannya. Seperti yang terungkap dalam pernyataan sebagai berikut: "Something was going on in her mind, something she could not name or stop; but it was almost as though she were her mind's prisoner, as though the jaws of her mind had closed on her" (Baldwin, 1962:125). Rahasia-rahasia ini membentuk suatu secret dungeon yang muncul dan memblokade penyingkapan. Ketika Cass dipisahkan, dan dipenjara oleh pikirannya, akan menjadi sulit untuk menunjukkan rahasianya, hubungan Cass dengan rahasia tersebut dan di mana Cass menyimpannya. Rahasia tersebut kemudian memenjarakannya dan membuat Cass terdisorientasi dengan perbedaan dirinya ketika menghadapi diri sendiri dan ketika dirinya berhubungan dengan dunia di luar dirinya. Pada konteks ini, dalam hubungannya dengan identititas, Woodward (1999) tidak menampik adanya kebenaran bahwa setiap diri manusia melalui perdebatan mereka sendiri perihal identitas mereka yang berkonflik, baik sebagai anggota komunitas etnis, kelas sosial, atau agama tertentu, sebagai anak, orang tua, pekerja dan lain sebagainya. 
Juga perlu diperhatikan adanya perspektif essensialist ${ }^{5}$ dan non-essentialist yang memandang identitas sebagai suatu cara pandang yang bergerak atau tidak bergerak. Lalu dalam konteksnya dengan orang hitam, Baldwin dalam Another Country telah jauh memandang dan memahami keyakinan non-esensialisme yang harus mengakui tidak hanya persamaan tetapi juga perbedaan karakteristik identitas. Dalam teksnya Baldwin menentang penyamaan arti menjadi seorang yang berkulit hitam di Amerika dalam jaman yang tidak lagi sama. Kutipan-kutipan di atas adalah gagasan Baldwin yang menunjukkan bahwa seseorang akan menemui kesulitan dalam memahami dirinya sendiri ketika ia tidak mencoba untuk meminta orang lain untuk memahami dirnya dengan cara membuka diri, atau membiarkan orang lain tahu perihal dirinya dengan mengatakannya sehingga orang lain tersebut dapat menempatkan posisinya pada tempat yang ia harapkan. Dari sudut pandang dan konteks ini, hal yang perlu dimaknai adalah bukan adanya perbedaan sejarah antara kelompok hitam, atau kelompok etnis atau bangsa lainnya, dengan kelompok putih penguasa saja, namun lebih kepada pemahaman bahwa perspektif ini dapat dijadikan konsep pembantu dalam pencarian identitas. Dengan perkataan lain, kita dapat menggunakan pertanyaan seperti yang diajukan Woodward (1991:11): is identity fixed? Can we find a true identity? dalam pencarian makna identitas yang lebih mendalam.

Menumpahkan segala pengalamannya sebagai manusia berkulit hitam yang homoseks, Baldwin mengakhiri ceritanya dengan semacam pembuatan janji melalui karakter-karakter dalam novel. Ida dan Vivaldo berjanji akan selalu menjadi sahabat yang saling mendukung dan tidak membedakan status sosial dan pilihan orientasi seks.

They stared at each other. Suddenly, he reached out and pulled her to him, trembling, with tears starting up behind his eyes... She clung to him; with a sigh she buried her face in his chest. There was nothing erotic in it; they were like two weary children. And it was she who was comforting him. Her long fingers stroked his back, and he began, slowly, with a horrible, strangling sound, to weep, for she was stroking his innocence out of him (Baldwin, 1962:431).

Melalui Ida dan Vivaldo, Baldwin menekankan dan memperluas gagasannya tentang diperlukannya another country atau tempat-tempat lain yang menihilkan pembedaan rasial dan mengedapankan pengakuan manusia sebagai mahluk yang sama. Baldwin ingin mengatakan bahwa dirinya, dan karakter-karakter yang ada dalam Another Country, menerima dan mengakui sepenuhnya perihal identitas mereka, dan kedua hal tersebut membawa mereka kepada suatu pengembangan diri yang lebih mendalam dan dewasa. Penerimaan dan pengakuan Baldwin atas kehitaman,

5 Dari akar katanya, Macey (2000:114) menjelaskan bahwa essentialism berasal dari kata essence yang berarti the true or permanent nature of being or phenomenon. Macey juga beranggapan bahwa Identity Politics adalah versi kontemporer dari essentialism. Hawthorne (2000:108) berujar bahwa sifat yang asli dan permanen, seperti yang dikatakan Macey, adalah sifat dasar yang self-evident sehingga tidak perlu dicari atau dijelaskan.

Dua Negara yang pada awalnya berada dibawah Socialist Federal Republic of Yugoslavia (SFRY). Federasi yang pada awalnya terdiri dari 6 negara - Bosnia and Herzegovina, Croatia, Macedonia, Montenegro, Serbia, and Slovenia harus terpecah pada tahun 1991 dan 1992 dengan perang yang disebut dengan the wars of Yugoslav succession. Woodward (1999) mengatakan bahwa 6 negara tersebut sebelumnya telah hidup bersama selama 50 tahun. 
kehomoseksualan dirinya juga harus dapat dimaknai orang lain, yaitu orang yang mengelilingi dan orang yang membaca teks Baldwin, sebagai suatu keindahan lain yang terdapat dalam diri dan bersifat universal. Dengan kata lain, permasalahan seksualitas dan ras bagi Baldwin adalah penghalang yang mesti diruntuhkan karena keduanya mencakup pemahaman yang luas akan suatu identitas.

Dalam mengupayakan hubungan Another Country, tafsiran pembaca dan konsep identitas, ungkapan Woodward dapat dijadikan landasan:

...identity is seen as fixed and unchanging. Sometimes these claims are based on nature; for example, 'race' and kinship in some versions of history and of the past, where history is constructed or represented as unchanging the truth. In fact identity is [relational]... (ditebalkan penulis, 1999:2)

Woodward (1999) mengatakan bahwa identitas seringkali dilihat hanya sebagai suatu kenyataan yang tidak akan berubah. Ketika membicarakan identitas yang diwariskan, warna kulit atau kehitaman James Baldwin misalnya, anggapan tersebut bisa jadi selalu benar. Namun ketika identitas dihubungkan dengan pengalaman-pengalaman hidup Baldwin, maka identitas dapat mempunyai makna yang perseorangan; artinya bahwa setiap orang memiliki pengalaman yang relational, atau yang pribadi, yang memungkinkan seorang hitam mengidentifikasikan dirinya berbeda dengan orang hitam yang lain. Maka kemudian, adalah benar bahwa untuk memiliki identitas, anggota-anggota kelompok harus memiliki kesamaan, namun identitas yang lain yang dimiliki anggota-anggota kelompok itu tidak dapat memisahkannya begitu saja dari kelompoknya tersebut. Dalam hubungannya dengan karya-karya Baldwin, Nelson (1985) beranggapan bahwa seksualitas, dalam keragaman kontradiksinya, adalah suatu penghalang yang harus dihilangkan. Nelson melihat tulisan Baldwin sebagai karya yang menunjukkan konfrontasi dan penerimaan Baldwin terhadap seksualitasnya dan sebagai perjuangan menuju a healing and liberating sense of selfacceptance yang kemudian termanifestasi dalam growing maturity of vision (Nelson, 1985: 11-16). Cara pandang, atau vision, ini yang lalu memastikan, atau paling tidak mencoba memastikan, tafsiran pembaca Baldwin terhadap Another Country. Selain Nelson, Porter juga mengungkapkan bahwa

...all of his (Baldwin's) writings, but especially his candid autobiographical essays are explained summarily as a relentless serch for identity. Critics view this quest for identity almost exclusively in the context or large social questions or private personal matters, such as his homosexuality (pengubahan oleh penulis,1989:14).

Determinasi dalam usahanya mencari dan menunjukkan siapa diri Baldwin inilah yang dikatakan Porter sebagai salah satu upaya yang umum atau universal yang dilakukan seseorang dalam menjajaki jati dirinya. Tafsiran, yang dapat diperdebatkan, itu adalah bahwa Baldwin tidak menulis Another Country hanya untuk menyampaikan gagasannya perihal permasalahan homoseksualitasnya saja, melainkan juga tentang gambaran yang lebih luas perihal perjuangan mempelajari hubungan yang universal, penerimaan diri dan kelompok lain yang berbeda beserta tanggung jawab-tanggung jawab yang menyertainya. Hal-hal tersebut lekat dalam dan sepanjang hidup Baldwin. Pengalamannya melahirkan tuliskan-tulisan yang kuat yang berhubungan dengan gagasan yang memperjuangkan kesetaraan sosial dan kaum homoseks. 


\section{SIMPULAN}

Penelitian dengan pembahasan Another Country telah menunjukkan gagasangagasan Baldwin dalam hubungannnya dengan permasalahan identitas di Amerika. Gagasan tersebut tersebut mencerminkan pengetahuan-pengetahuan Baldwin, keyakinan-keyakinan dan nilai-nilai budaya yang dianutnya sebagai seorang Amerika keturunan. Penelitian ini juga telah menunjukkan usaha pembebasan diri Baldwin dari aturan, perlakuan dan normanorma yang membatasi, menghilangkan hak-hak alamiah diri dan kelompoknya. Sebagai warga kulit hitam yang memiliki pengetahuan dan pengalaman yang tidak menguntungkan, Baldwin mencoba untuk mengungkapkan perasaan-perasaannya yang segolongan - yang homoseksual dan yang berkulit hitam - dalam bentuk penyampaian gagasan-gagasan pada Another Country dengan sasaran utama warga kulit putih, sistem legal atau sosial dan asumsi-asumsi mereka yang mengatur perlakuan mereka terhadap warga Afrika Amerika.

\section{DAFTRA PUSTAKA}

Baldwin, James. 1962. Another Country. New York:Vintage Books.

Baldwin, J., Standley, F. L., \& Pratt, L. H. 1989. Conversations with James Baldwin. London: Univ. Press of Mississippi.

Barthes, Roland. 1998. "The Death of the Author" Art and Interpretation: An Anthology of Readings inAesthetics and the Philosophy of Art. Peterborough: Broadview

Campbell, J. 1991. Talking at the Gates: A Life of James Baldwin with a New Afterword. Berkeley: Univ of California Press.

Eckman, Fern Marja. 1966. The Furious Passage of James Baldwin. New York: M. Evans \& Company.

Foucault, M., 1980. Power/Knowledge: Selected Interview and Other Writings, 1972-1977 (edited by Colin Gordon), Brighton: Penguin Books.

Gandhi, Leela. 1998. Postcolonial Theory: A Critical Introduction. New York: Columbia University Press.

Gates, H. L., \& McKay, N. Y. 1997. African American Literature (Vol. 997). New York: Norton. Gutmann, Amy. 1994. Multiculturalism. Princeton: Princeton University Press.

Hawthorne, Jeremy. 2000. A Glossary of Contemporary Literary Theory. London: Arnold.

Heraty, Toeti. 2000. Hidup matinya sang pengarang: Esai-esai tentang kepengarangan oleh sastrawan dan filsuf. Jakarta: Yayasan Obor Indonesia

Keraf, Gorys. 1993. Komposisi: Sebuah Pengantar Kemahiran Bahasa. Ende: Nusa Indah.

Macey, David. 2000. The Penguin Dictionary of Critical Theory. England: Penguin Books.

Miller, D. Q. 2000. Re-viewing James Baldwin: things not seen. Temple University Press.

Nelson, Emmanuel.1985. The Novels of James Baldwin: Struggles of Self-Acceptance. Journal of American Culture.

Porter, Horace A. 1989. Stealing the Fire: The Art and Protest of James Baldwin. Connecticut: Wesleyen University.

Ryan, Gery W and H. Russel Bernard. 2003. "Techniques to identify themes". Fields Methods. 1(15), 85-109. DOI : 10.1177/1525822X02239659

Wellek and Warren. 1997. Theory of Literature. New York ; London : Harcourt Brace Jovanovich.

Woodward, Kathryn. 1999. Identity and Difference. London: SAGE Publications. 